\title{
Ethno-medicinal plants used for herbal medication of jaundice by the indigenous community of Tripura, India
}

\author{
DIPANKAR DEB ${ }^{1}$, B.K. DATTA ${ }^{2}$, JABA DEBBARMA ${ }^{1, \boldsymbol{\varphi}}$, SOURABH DEB ${ }^{2}$ \\ ${ }^{1}$ Agroforestry and Forest Ecology Laboratory, Department of Forestry and Biodiversity Tripura University (A Central University), Suryamaninagar \\ 799022, Tripura, India. Tel. 0381-237-9093, Fax. 0381-237-4807, ’email: jaba.forestry@tripurauniv.in \\ ${ }^{2}$ Plant Taxonomy and Biodiversity Laboratory, Department of Botany, Tripura University (A Central University), Suryamaninagar 799022, Tripura, India
}

Manuscript received: 30 December 2015. Revision accepted: 1 April 2016.

\begin{abstract}
Deb D, Datta BK, Debbarma J, Deb S. 2016. Ethno-medicinal plants used for herbal medication of jaundice by the indigenous community of Tripura, India. Biodiversitas 17: 256-269. The immemorial association of medicinal plants is highlighted in various utilization pattern by different indigenous community. An investigation was done for less known ethno-medicinal plants used for jaundice as well as some other ailments by the indigenous community of Tripura, Northeast India. The traditional utilization of plants for treatment of jaundice by the indigenous communities is not so well studied in the land locked hilly part of the country. Timely ethnobotanical survey was undertaken with the knowledge of the species mainly used for curing jaundice. Necessary specimens were collected and cross-checked with the existing literatures. A total of 50 ethno-medicinal plant species belonging to 37 families were documented used for the treatment of jaundice (45 plant species with an additional ingredient of 5 species) and other diseases. Mainly leaves and roots were preferred to prepare decoction, pills and paste etc. Most of the plant species are sources of different chemical constituents which further contribute in formulating drug for common use. The active biochemical compounds are investigated by thorough literature survey. There is need for further critical phytochemical analysis and investigation of new valid drugs. Immediate documentation of such valuable knowledge is necessary as we are gradually missing many precious traditional herbal formulations with increasing impacts of modernization.
\end{abstract}

Keywords: Antioxidant, herbal formulation, indigenous community, jaundice, phytochemical

\section{INTRODUCTION}

An indigenous community seems to hold the habitual knowledge of herbal remedies for different minor to chronic diseases. Such indigenous identity of the particular community is derived due to the immemorial association with their floral and faunal environment. This association has led to the use of many plants for food, fodder and medicine (Abbasi et al. 2009). The local folks are therefore dependent on various aspects of herbal formulations for curing different ailments (Annalakshmi et al. 2012). This traditional knowledge has been passing on verbally from one generation to another (Majumdar et al. 2006) which is equivalent to the irreversible loss of flora and fauna (Bora et al. 2012). However, there is always a chance to loss of this knowledge rather than leaving behind to next generations. Thus the customary approach to document the knowledge about the medicinal properties of plants for curing different diseases has become indispensable before it is lost perpetually.

Northeast region of India is considered as an abode of more than $50 \%$ of total ethnic communities present in the country with a unique folklore (WHO 2001). These ethnic people are living in remote areas with closest harmony to the adjacent forest. Their livelihood subsistence greatly depends on biotic resources available in that area (Deb et al. 2012). The indigenous community people are not well concerned about any modern medicinal facilities due to their restricted socio-economic condition. Therefore, the ethnic people from various parts of Northeast India are greatly inevitable with contingent on plant-based healing to their health care needs by indefinite cohorts (Majumdar and Datta 2007; Das et al. 2008).

The Northeastern part of India consists of half of the total flora of India (Lokho 2012) and Tripura also harbor varieties of medicinal plants (Singh et al. 1997; Majumdar et al. 2006; Majumdar and Datta 2007; Das et al. 2009; Das et al. 2012). The ethno-medicinal study is regarded as most feasible method for identifying new medicinal plants used for customary health care practices propagated by the ethnic communities (Annalakshmi et al. 2012). This is attracting the attention of several scientists to uphold direction to keen research towards the unearthing of several herbal remedies (Bhattacharya and Goel 1981; Karuppasmy 2007; Manikandan et al. 2009). Among them many workers throughout the globe have reported the usefulness of plants from several chronic to minor diseases like diabetes, dysentery, urinary disorder, jaundice etc. (Raman and Lau 1996; Matsuda et al. 2001; Abbasi et al. 2009; Zulfiker et al. 2010; Rahim et al. 2012; Annalakshmi et al. 2012; Karmakar et al. 2012; Marrufo et al. 2013; Doss and Anand 2014; Islam et al. 2015).

Jaundice is a disorder which occurs when the bilirubin content in the blood is excessive due to haemolysis (Annalakshmi et al. 2012; Rahim et al. 2012; Jayachandra and Devi 2012). It is a yellowish discoloration of the skin, sclera, eyeballs, nails and mucous membrane. It indicates disorder in liver or gall bladder; occurs mostly in the 
newborn babies as they do have the immature liver which cannot regulate the amount of bilirubin like an adult (Guyton 2005; Jayachandra and Devi 2012). It is one of the most common diseases in the less developed countries and in the Asian countries as well (Karmakar et al. 2012).

According to the oldest codified system of medicine from South India, the Siddha system of medicine illustrates jaundice as one of the pitha type of disease (Annalakshmi et al. 2012). However, in modern allopathic and homeopathic medicine there is no unique treatment for jaundice (Abbasi et al. 2009). Whereas, people relatively preferred the non-codified system like folk medicine prescribed by the rural communities. Although, different ethnobotany workers has mainly documented the less known herbal remedies curing jaundice along with other diversified diseases by the ethnic communities from Northeast India (Deb 1968; Singh et al. 1997; Kala 2005; Majumdar and Datta 2007; Sajem et al. 2008; Sikdar and Dutta 2008; Shil and Choudhury 2009; Das et al. 2009; Rai and Lalramnhinglova 2010; Das and Choudhury 2010; Sahu et al. 2011; Choudhury et al. 2012; Das et al. 2012; Das and Choudhury 2012; Jayachandra and Devi 2012; Dutta and Sharma 2013). However, to our acquaintance no sole systematic explorations on application of medicinal plants against jaundice have been made so far in Tripura. In this context, the present study is the first landmark with meticulous emphasis on less known medicinal plants used for jaundice by the indigenous communities of Tripura.

\section{MATERIALS AND METHODS}

\section{Study site}

The present study is the outcome of bioresource survey throughout the state of Tripura, India during 2013-2015. It is a hilly state in the northeastern part of India which lies between $22^{\circ} 56^{\prime}$ to $24^{\circ} 32^{\prime} \mathrm{N}$ latitude and $90^{\circ} 09^{\prime}$ to $92^{\circ} 20^{\prime} \mathrm{E}$ longitude. It is bordered internationally with Bangladesh in the North, West and South. Nationally bordered with two sister states Mizoram in the east and Assam in the northeast. The state has 19 ethnic communities distributed throughout the 8 districts. The survey conducted in the remote areas of community dwelling places like Kanchanpur, Gandacherra, Baramura, Twidu, Amarpur, Karbook, etc. (Figure 1). The major inhabitants of these areas were Tripuri, Jamatia, Halam, Santhal and nontribal community.

\section{Data collection}

The ethnobotanical data were collected by conducting a questionnaire survey and formal group discussions. In the survey, details of the species were asked which are mainly used for curing jaundice along with some other ailments. Vernacular names, parts used, composition and dosages were recorded to validate the curing process. Some precautions were also noted down for each use of the species composition. The details were carefully recorded. The species were identified by visiting in their natural growing sites. During the survey necessary specimens were collected to ensure the species identification. The botanical names along with author names were cross-checked with the help of IPNI website (http://www.ipni.org) and existing literatures (Deb 1981, 1983). Further, the phytochemical constituents of recorded plant species were also collected after thorough literature survey.

\section{RESULTS AND DISCUSSION}

\section{Results}

A total of 50 species were documented which are used in treating jaundice. The species are enumerated in a tabular form along with the scientific names, family

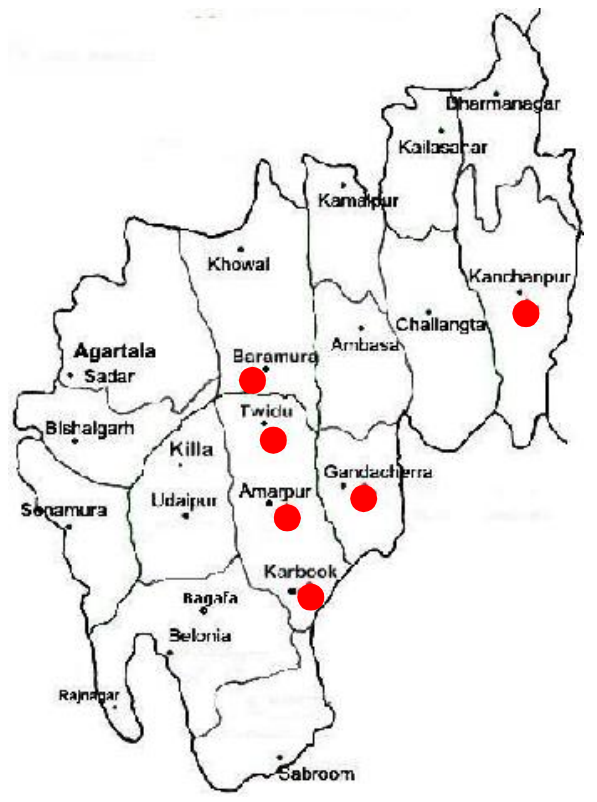

Figure 1. Study site in the state of Tripura, India 
names, vernacular names, parts used, composition, dosage, additional materials added and some recommended precautions (Table 1). The recorded genus and species were 46 and 45 respectively belonging to 37 families. The dominant family is Rutaceae contributed by 4 species, Acanthaceae (3 species) followed by Convolvulaceae, Cucurbitaceae and Mimosaceae with 2 species each. Whereas, the rest 32 families with single species each, which include Anacardiaceae, Apiaceae, Costaceae, Euphorbiaceae, Lamiaceae, Menispremaceae, Plumbaginaceae, etc. (Figure 2). The parts utilized for various ailments were whole plants, stems, leaves, fruits, barks and roots. The most widely used parts were leaf/twigs (38\%) > roots/rhizome $(18 \%)$, fruits $(16 \%)>$ stems $(11 \%)>$ barks $(8 \%)>$ whole plant $(7 \%)$ and $2 \%$ tuber. Figure 3 highlights the utilization pattern of plant parts with the percentage of uses.

The leaves are mostly taken in the form of decoction, raw, paste, powder and often juice is extracted for regular consumption. But even some are included in their daily diet by boiling for making curry. The species includes viz. Azadirachta indica A. Juss., Asteracantha longifolia Nees., Cajanus cajan (L.) Millsp., Citrus limon (L.) Osbeck, Eclipta alba L. ex B.D. Jacks, Hibiscus surattensis L., Kalanchoe pinnata Pers., Mangifera indica L., Marsilea minuta L., Scoparia dulcis L., Typhonium trilobatum (L.) Schott etc. Roots of Citrus limon (L.) Osbeck, Glycosmis arborea (Roxb.) DC., is utilized in the form of decoction. Often roots are also taken in the form of paste or powder form from species such as Costus speciosa (J. Koenig) Sm., Entada phaseoloides (L.) Merr., Ichnocarpus frutescens (L.) R. Br., Plumgabo zeylanica L., Smilax zeylanica L., Solanum nigrum L. and Thunbergia grandiflora Roxb. Most of the fruits are taken raw or when ripen (Averrhoa carambola L., Garcinia pedunculata Roxb. ex Buch.-Ham, Phyllanthus nirruri Roxb. ex Wall) and sometimes juice is extracted for consumption (Citrus medica L., Momordica charantia L.). The species whose barks are utilized are Mangifera indica L., Micromelum integerrimum (Roxb. ex DC.) Wight Arn. ex M. Roem; Oroxylum indica (L.) Benth. ex Kurz and Ziziphus oenoplia (L.) Mill. Bark paste of Mangifera indica $\mathrm{L}$. is used to cure jaundice by rubbing against body before bath for 3-4 days, as the water color changes to orange, this practice is believed to cure jaundice as reported by local medical practitioners.

A total of 45 species out of 50 were recorded for treating jaundice including five species which are used as an additional ingredient added to prepare medicine. The additional species used includes Allium sativum L., Allophyllus racemosa L., Cassia fistula L., Piper longum L. and Zingiber officinale L. A number of ailments were recorded from this study other than jaundice. The key pointed ailments mentioned were worm (intestinal/ stomach), gum/tooth problem, anemia, dysentery, ophthalmic problem, kidney stone, diabetes, cough, skin disease, urinary disorder, snake bite and wound healing. During the treatment of jaundice, diet of the patient is highly taken care of and suggested to take food which keeps the body temperature cool. Therefore, oil rich foods were not included in diet. Generally high nutritious leafy green vegetables were advised to take.

The plant parts are taken in different forms as represented in Table 1. Decoction was mostly taken for all the parts utilized, followed by raw, paste, juice, powder, boil, crushed and cooked as food. These parts are taken either in a single or conjugated with some other additional materials like scented rice (Oryza sativa L.), Coccinia grandis (L.) Voigt, Catharanthus roseous L., salt, calcium hydroxide etc. either orally or is applied in case of wound healing or washing during gum or tooth ache.

The phytochemical constituents of species preferred for curing jaundice are assembled after critical review of literatures (Table 2). The identified compounds were known to have beneficial importance in medical science and also for industrial purposes.

The common constituents like carbohydrate, vitamin and minerals ensure about the utility of the material in regular diet. These phytochemicals provide pharmacological and therapeutic effects upon its use. Besides, these are also providing nutrition in our daily diet. Fruits of Averrhoa carambola L. is consumed during the occurrence of jaundice. It is indicated to contain a huge amount of antioxidant properties. These antioxidants significantly delays or prevents oxidation of oxidisable substrate that protects the body against damage caused by reactive oxygen. Alocasia indica (Roxb.) Schott. is well preferred

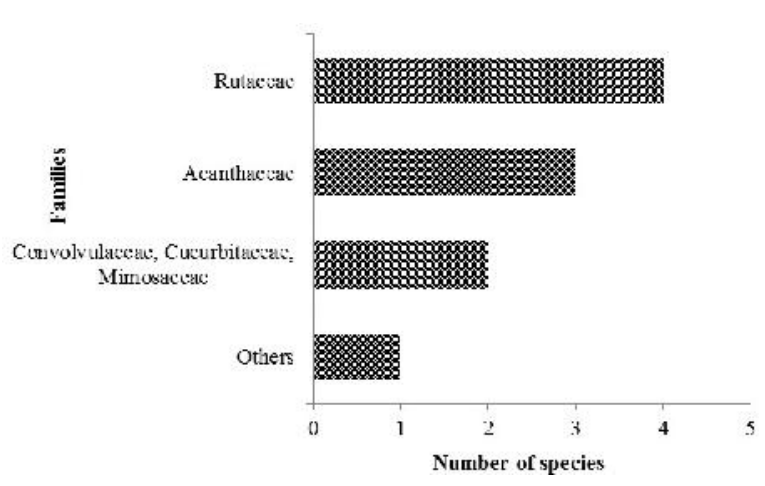

Figure 2. Taxonomic enumeration of the recorded plant species

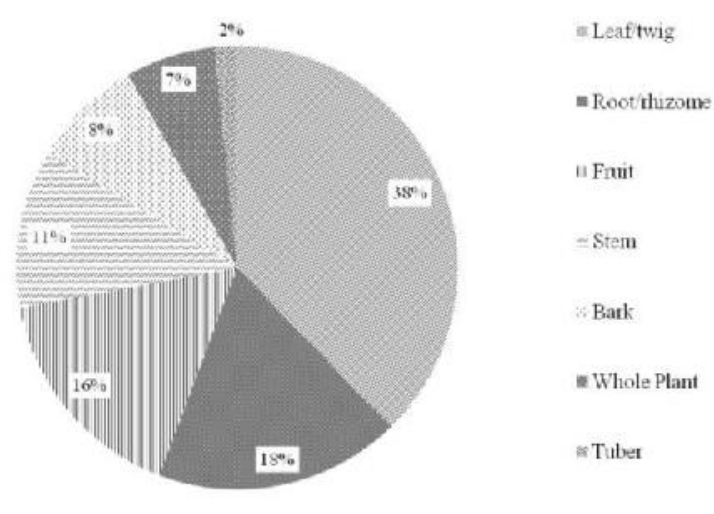

Figure 3. Utilization pattern of the recorded plant parts 
vegetable of community's regular diet. Tubers of this plant have diagnostic effects due to the presence of compounds like phenolic acids and flavonoids. Enhydra fluctuans Lour. is another species, whose leaves are taken after boiling, contains sesquiterpene lactones. The other species which possess the same compounds are Citrus medica L., Centella asiatica (L.) Urb., Coccinia grandis (L.) Voigt, Mangifera indica L., Neptunia prostrata Baill., Terminalia bellirica (Gaertn.) Roxb. among others, listed for its beneficial chemical compounds. Centella asiatica (L.) Urb. is possessing an array of chemical constituents like asiatica, asiaticoside, betulinic acid, thankunic acid and isothankunic acid and many other beneficial active chemical component, which have cognitive enhancing effect, neuroprotective effect and influences oxidative stress parameters (Orhan 2012).

\section{Discussion}

The present study shows the preferences of many herbal medicines to cure varieties of ailments mainly jaundice, dysentery, intestinal worms, wound healing, ophthalmic problem, etc. An appraisal of other reports simplified that various species have some similarities across the communities in the same geographical region. Species like Azadirachta indica A. Juss., Cajanus cajan (L.) Millsp., Carica papaya L. Centella asiatica (L.) Urb. and Oroxylum indicum (L.) Benth. ex Kurz were found to be used against jaundice in Manipuri communities (Das and Choudhury 2012) and in Darlong communities (Deb et al. 2012). In the present study the use of species like Cuscuta reflexa Roxb. and Glycosmis arborea (Roxb.) DC. against jaundice are found similar with other studies (Majumdar et al. 2006; Das et al. 2009). This may be due to the inter-cultural homogeneity in the knowledge of the significant uses.

Many above and below ground parts were utilized in the form of decoction, food, paste, as fruit, powder, juice, crushed form, by soaking, by forming pills and others like brushing etc. The maximum parts utilized were above ground like leaves, stems and fruits which was found to be similar with the reports (Sen et al. 2011). Mishra et al. (2012) reported 15 species for curing jaundice out of 68 species from Tarai region of Uttar Pradesh.

Costus speciosus (J. Koenig) Sm. was recorded from the present study against jaundice. However, the same species was reported against kidney stone (Shankar et al. 2012) and diabetes (Choudhury et al. 2012). It shows the importance of the species irrespective of the location. In the present study, fruits of Phyllanthus niruri Roxb. ex Wall was recorded for treating jaundice which was similar with the others' findings (Sikdar and Dutta 2008; Sen et al. 2011; Das et al. 2012). The significant effects of the use of Phyllanthus niruri Roxb. ex Wall in treating jaundice has also been shown by chemical analysis (Jayachandra and Devi 2012). Plumbago zeylanica L. in the present study is found to be used in treating snake bite. But instead of this plant some other plant parts was reported for the same treatment (Lokho 2012). These differences may be due to the lack of knowledge and known effects of the same. It also signifies the same phytochemical properties of different species.
The listed plants have different kind of chemical constituents (Table 2). The components are different types of essential to secondary metabolites viz. vitamins, glycosides, tannins, flavonoids etc. It is assumed that these compounds are responsible for the various physiological activitites. Among the Vitamins, exact physiological role of Vitamin A is essential in vision. The main precursor of the rhodopsin is Vitamin A, as well as it boosts up immunity power (Igwenyi et al. 2011). Vitamin B (riboflavin) is essential for energy production and in its coenzyme forms (FMN and FAD) serves as hydrogen transport systems (Mayes 2000). Vitamin C, an antioxidant, facilitates wound healing, production of collagen, formation of red blood cells and boosts immune system (Monsen 2000). Some other vitamins act as an antioxidant and also plays a role in cellular respiration (Burtis and Ashwood 2003), coenzymes for various oxidoreductases. Besides, alkaloids are well known for their ability to inhibit pain.

The sugar molecules of many plant glycosides are often bound to poisons in order to move them from the body. The tannins prevent urinary tract infection by preventing bacteria from adhering to the walls (Igwenyi et al. 2011). Cholesterol is breakdown in the blood stream by the combine action of tannin and anthocyanins. Tannins also help build and strengthen collagen along with vitamin $\mathrm{C}$ (Okuda et al. 1991). During infections and microbial invasions in body saponins serve as natural antibiotics. It can also enhance the effectiveness of certain vaccines, lower cholesterol level and destroy lung \& blood cancer tumor cells. Flavonoids have antioxidant activity, antiallergic; prevent from inflammation, free radicals, platelet aggregation, microbes, ulcers, hepatoxins and tumors in biological systems (Okwu and $\mathrm{Ndu}$ 2006). Thus the presence of good amount of phytochemicals can provide and protect body's physiological process against different damaging effects (Igwenyi et al. 2011).

These chemical constituents are tested for several physiological disorders and as a whole these are screened out by pharmacological tests for specific and particular ailments (Raman and Lau 1996; Xie et al. 1998; Ito et al. 2004; Atangwho et al. 2009; Zulfiker et al. 2010; Orhan 2012; Islam et al. 2015). Besides, the present study reports the usefulness of these plants to prepare herbal formulation for jaundice. So there is a need for some specific phytochemical screening, whether these listed chemicals exactly perform to cure jaundice or not?

In conclusion, indigenous communities are habituated to live around the natural resources and utilizing the resources. This practice of plant product utilization is build up based on the trial and error method. Plants are the repository of potential medicinal values thus can be widely used for alleviating several health problems. New formulations of drugs are based on the local trials by the indigenous people. But due to the absence of the modern medicine and existence of the belief in the effect of the herbal drugs, people in the rural area still prefer traditional ways of curing. Species like Ensete glacum (Roxb.) Cheesm and Thunbergia grandiflora Roxb. are newly reported for their use in jaundice and hence require a necessary attention in finding the new chemical 
Table 1: Enumeration of the recorded plant species with their scientific, vernacular and family names along with their parts used and dosages.

\begin{tabular}{|c|c|c|c|c|c|c|c|}
\hline Species & Family name & Vernacular name & Part (s) & Composition & Dosage & $\begin{array}{c}\text { Additional } \\
\text { materials }\end{array}$ & Precautions \\
\hline $\begin{array}{l}\text { Alocasia indica (Roxb.) } \\
\text { Schott. }\end{array}$ & Araceae & Kochu (B), Muitu (K) & Tuber & Tuber is boiled and taken as food & $\begin{array}{l}4-5 \text { days during } \\
\text { jaundice }\end{array}$ & - & - \\
\hline $\begin{array}{l}\text { Andrographis paniculata } \\
\text { (Burm. f.) Wall. ex Nees }\end{array}$ & Acanthaceae & Chirata $(\mathrm{K})$ & Whole Plant & Whole plant decoction & $\begin{array}{l}\text { Administered } 2-3 \\
\text { table spoon in a day } \\
\text { for at least } 5 \text { days }\end{array}$ & $\begin{array}{l}\text { Zinger (Zingiber } \\
\text { officinale L.) }\end{array}$ & - \\
\hline Asteracantha longifolia Nees. & Acanthaceae & Kulekhara (B) & Leaf & Leaf decoction or either eaten raw & Until cure & - & - \\
\hline Averrhoa carambola $\mathrm{L}$. & Oxalidaceae & Kamaranga $(\mathrm{B} / \mathrm{K})$ & Fruit & $\begin{array}{l}\text { Fruit is advised to consume during } \\
\text { jaundice }\end{array}$ & - & - & - \\
\hline Azadirachta indica A. Juss. & Meliaceae & Neem $(B / K)$ & Leaf & $\begin{array}{l}\text { Dry leaves powder is taken with warm } \\
\text { rice. }\end{array}$ & 3-4 weeks & $\begin{array}{l}\text { Warm rice (Oryza } \\
\text { sativa } \mathrm{L} \text {.) }\end{array}$ & - \\
\hline Bacopa monnieri (L.) Pennell & Scrophulariaceae & Bramhi (B) & Leaf & Leaf juice is given until cure & $10-20 \mathrm{ml}$ daily & - & - \\
\hline Cajanus cajan (L.) Millsp. & Papilionaceae & $\begin{array}{l}\text { Arahar, Aroll (B), } \\
\text { Khakleyng }(\mathrm{J}) \text {, } \\
\text { Muimasing }(\mathrm{K})\end{array}$ & Leaf, Fruit & $\begin{array}{l}\text { Decoction of leaf and also cooked } \\
\text { Pulses are burnt with stem of Mangifera } \\
\text { indica, leaf of Musa paradisiaca and the } \\
\text { leg skin of chicken. A paste is prepared } \\
\text { from the ashes after burning and applied } \\
\text { on gum and tooth by Jamatia. }\end{array}$ & $\begin{array}{l}\text { 5-6 tea spoons in } \\
\text { empty stomach }\end{array}$ & $\begin{array}{l}\text { Mangifera indica } \\
\text { L. (Thaichuk), } \\
\text { Musa paradisiaca } \\
\text { L. (Jay Thailwk), } \\
\text { chicken leg skin }\end{array}$ & - \\
\hline Carica papaya $\mathrm{L}$. & Caricaceae & Kuwaifal (K) & Fruit & Eaten raw or even curry is prepared & Advised to take daily & - & $\begin{array}{l}\text { Without oil, } \\
\text { Garlic }\end{array}$ \\
\hline Centella asiatica (L.) Urb. & Apiaceae & $\begin{array}{l}\text { Thankuni, Adamoni } \\
\text { (B), Ankhnaleng (H), } \\
\text { Shamshota (K) }\end{array}$ & Whole plant & $\begin{array}{l}\text { Whole plant parts crushed and } \\
\text { decoction is given for curing jaundice. } \\
\text { It is also eaten raw or is crushed and the } \\
\text { extraction is taken with warm rice. } \\
\text { Very popular vegetable item among the } \\
\text { Tripuri tribe. }\end{array}$ & - & Warm rice & - \\
\hline Citrus limon (L.) Osbeck & Rutaceae & $\begin{array}{l}\text { Kagajilebu (B), Janbi } \\
\text { (J) }\end{array}$ & Root, Leaf & $\begin{array}{l}\text { The root decoction is very effective in } \\
\text { curing hepatitis. } 2-3 \text { leaves rubbed with } \\
\text { finger, are given for smelling to bring } \\
\text { sense. } \\
\text { Washing with the water of the boiled } \\
\text { leaves during ophthalmic problem }\end{array}$ & $\begin{array}{l}\text { Root decoction taken } \\
\text { one cup for a month. }\end{array}$ & - & $\begin{array}{l}\text { Root decoction } \\
\text { taken in empty } \\
\text { stomach. } \\
\text { Wash properly } \\
\text { after cooling. }\end{array}$ \\
\hline Citrus medica $\mathrm{L}$. & Rutaceae & $\begin{array}{l}\text { Baranebu, Jamir (B), } \\
\text { Jami }(\mathrm{K})\end{array}$ & Fruit & $\begin{array}{l}\text { Decoction of ripe fruits is taken in more } \\
\text { quantities. }\end{array}$ & - & - & $\begin{array}{l}\text { Fruit must be } \\
\text { ripened }\end{array}$ \\
\hline Coccinia grandis (L.) Voigt & Cucurbitaceae & $\begin{array}{l}\text { Thelakuchu (B) } \\
\text { Tokhathaichumu (K) }\end{array}$ & Leaf & Leaf decoction & $\begin{array}{l}\text { Taken for } 2-3 \\
\text { teaspoon for } 5 \text { days }\end{array}$ & - & - \\
\hline
\end{tabular}




\begin{tabular}{|c|c|c|c|c|c|c|c|}
\hline Cocos nucifera $\mathrm{L}$. & Arecaceae & $\begin{array}{l}\text { Narikol (B) } \\
\text { Narikwra (K) }\end{array}$ & Fruit & Coconut milk, nutritive soft endosperm & $\begin{array}{l}\text { Advice to take } \\
\text { regularly }\end{array}$ & - & - \\
\hline $\begin{array}{l}\text { Costus speciosus (J. Koenig) } \\
\text { Sm. }\end{array}$ & Costaceae & $\begin{array}{l}\text { Kebuk }(\mathrm{H}) \text {, Kushtha, } \\
\text { Keora }(\mathrm{K})\end{array}$ & $\begin{array}{l}\text { Rhizome, } \\
\text { Leaf, Root }\end{array}$ & $\begin{array}{l}\text { Paste of rhizome taken during kidney } \\
\text { stone. } \\
\text { Taken as food. } \\
\text { Leaves and root juice taken to cure } \\
\text { diabetes }\end{array}$ & - & - & - \\
\hline Cuscuta reflexa Roxb. & Convolvulaceae & $\begin{array}{l}\text { Sarnalata (B), Ruiengte } \\
(\mathrm{H}) \text {, Jirai }(\mathrm{K})\end{array}$ & $\begin{array}{l}\text { Whole plant } \\
\text { part }\end{array}$ & $\begin{array}{l}\text { Decoction of the plant along with } \\
\text { coconut water taken in severe jaundice. } \\
\text { Stem is crushed, extracted, filtered and } \\
\text { given to jaundice patient by Halam. } \\
\text { Decoction is prescribed during cough } \\
\text { and diabetes and also } \\
\text { Plant scattered on the bed to prevent } \\
\text { night bed urinate. }\end{array}$ & $\begin{array}{l}\text { Decoction (1-2 cups) } \\
\text { taken for } 2 \text { weeks at } \\
\text { early morning along } \\
\text { with } 2-3 \text { cups of } \\
\text { coconut water. } \\
40-50 \text { gm of stem } \\
\text { must be crushed and } \\
\text { extracted. }\end{array}$ & Cocos nucifera $\mathrm{L}$. & $\begin{array}{l}\text { It is advised to } \\
\text { drink the } \\
\text { decoction facing } \\
\text { the sun in } \\
\text { standing position } \\
\text { and later get } \\
\text { heated up in } \\
\text { sunlight for } 5 \\
\text { minutes. }\end{array}$ \\
\hline Enhydra fluctuans Lour. & Asteraceae & $\begin{array}{l}\text { Helencha }(\mathrm{B}) \\
\text { Elencha }(\mathrm{K})\end{array}$ & Leaf & Boiled leaf & $\begin{array}{l}\text { Boiled leaf and stem } \\
\text { are taken with rice }\end{array}$ & - & No limits \\
\hline $\begin{array}{l}\text { Ensete glaucum (Roxb.) } \\
\text { Cheesm }\end{array}$ & Musaceae & Chisau (L) & Pseudo-stem & Pseudo stem is eaten raw & Can take any time & - & - \\
\hline $\begin{array}{l}\text { Entada phaseoloides (L.) } \\
\text { Merr. }\end{array}$ & Mimosaceae & $\begin{array}{l}\text { Gila (B), Swkwi-bakhla } \\
(\mathrm{K})\end{array}$ & Root bark & $\begin{array}{l}\text { Paste of root bark is made and taken in } \\
\text { very low quantity with water }\end{array}$ & - & - & - \\
\hline $\begin{array}{l}\text { Garcinia pedunculata Roxb. } \\
\text { ex Buch.-Ham }\end{array}$ & Clusiaceae & Borthekera $(\mathrm{K})$ & Fruit & $\begin{array}{l}\text { Advised to take raw fruits during } \\
\text { jaundice }\end{array}$ & - & - & - \\
\hline $\begin{array}{l}\text { Glycosmis arborea (Roxb.) } \\
\text { DC. }\end{array}$ & Rutaceae & TuluthaPoka (K) & Root & Decoction & $\begin{array}{l}5-6 \text { teaspoon of } \\
\text { decoction is mixed } \\
\text { with milk }\end{array}$ & Milk & $\begin{array}{l}\text { Patients suffering } \\
\text { with rheumatic } \\
\text { pain must avoid }\end{array}$ \\
\hline Hibiscus surattensis $\mathrm{L}$. & Malvaceae & Sarba-ameli (B) & Leaf & $\begin{array}{l}\text { Special type of curry is made by its } \\
\text { tender leaves }\end{array}$ & - & - & - \\
\hline $\begin{array}{l}\text { Ichnocarpus frutescens (L.) R. } \\
\mathrm{Br} \text {. }\end{array}$ & Apocynaceae & $\begin{array}{l}\text { Dugdhalata, Perialata } \\
\text { (B), Soya lata (S) }\end{array}$ & Root, Bark & $\begin{array}{l}\text { Juice of the mixture of old root barks of } \\
\text { the plant and Ziziphus oenoplia (L.) } \\
\text { Mill. }\end{array}$ & $\begin{array}{l}\text { Juice taken twice a } \\
\text { day after filtration } \\
\text { along with } 1-2 \text { spoon } \\
\text { sugar }\end{array}$ & $\begin{array}{l}\text { Root bark of } \\
\text { Ziziphus oenoplia } \\
\text { (L.) Mill. } \\
\text { (Banbadai) }\end{array}$ & $\begin{array}{l}\text { The root bark } \\
\text { must be old. } \\
\text { Mixtures must be } \\
\text { in equal ratio. }\end{array}$ \\
\hline Ipomoea aquatica Forssk. & Convolvulaceae & Kamli (B) & Stem, Leaf & Plant parts are boiled to prepare dish & Consumed with rice & - & - \\
\hline
\end{tabular}




\begin{tabular}{|c|c|c|c|c|c|c|c|}
\hline Mangifera indica $\mathrm{L}$. & Anacardiaceae & $\begin{array}{l}\text { Am (B), Thaaychuk (J), } \\
\text { Thaichuk (K) }\end{array}$ & $\begin{array}{l}\text { Bark, Young } \\
\text { leaf, Stem }\end{array}$ & $\begin{array}{l}\text { Bark paste is boiled and water used } \\
\text { during bath during Jaundice (Pallang). } \\
\text { In this process few Calcium Hydro- } \\
\text { oxide rubbed on the body and after few } \\
\text { minutes that warm water slowly applied } \\
\text { over the body. Then the water color } \\
\text { quickly changes into orange color and is } \\
\text { called Pallang by local medical } \\
\text { practitioner. } \\
\text { Soaked bark given in case of blood } \\
\text { dysentery by Jamatia. } \\
\text { Leaf is chewed to control obesity. } \\
\text { Stem used as tooth brush to prevent } \\
\text { dental diseases. }\end{array}$ & $\begin{array}{l}\text { Bark soaked in water } \\
\text { given in empty } \\
\text { stomach. }\end{array}$ & $\begin{array}{l}\text { Calcium Hydro- } \\
\text { oxide (Chun) }\end{array}$ & $\begin{array}{l}\text { Bark paste is } \\
\text { boiled with water } \\
\text { for about } 10 \\
\text { minutes } \\
\text { Bark is soaked } \\
\text { overnight in a } \\
\text { glass of water. } \\
\text { Leaves and stem } \\
\text { used must be } \\
\text { young. }\end{array}$ \\
\hline Marsilea minuta $\mathrm{L}$. & Marsileaceae & Susni (H) & Leaf & $\begin{array}{l}\text { Soup is prepared with its leaves and is } \\
\text { included in regular for } 15 \text { days }\end{array}$ & - & - & - \\
\hline $\begin{array}{l}\text { Micromelum integerrimum } \\
\text { (Roxb. ex DC.) Wight Arn. ex } \\
\text { M. Roem. }\end{array}$ & Rutaceae & $\begin{array}{l}\text { Bon Jamir (B), Karai } \\
(\mathrm{K})\end{array}$ & Fruit, Bark & $\begin{array}{l}\text { Fruits are taken during jaundice. } \\
\text { Bark decoction to cure dysentery. }\end{array}$ & $\begin{array}{l}\text { Decoction given in } \\
\text { empty stomach }\end{array}$ & - & $\begin{array}{l}\text { Fruits must be } \\
\text { matured }\end{array}$ \\
\hline Momordica charantia $\mathrm{L}$. & Cucurbitaceae & Korola (B), Gangla (K) & Fruits, twigs & $\begin{array}{l}\text { Extract of fruits and twigs prepared and } \\
\text { taken in small quantity }\end{array}$ & - & - & - \\
\hline Moringa oleifera Lam. & Moringaceae & Sajna (B/K/H) & Leaf, stem & $\begin{array}{l}\text { Juice from crushed leaves and stems is } \\
\text { taken }\end{array}$ & - & - & - \\
\hline Neptunia prostrata Baill. & Mimosaceae & $\begin{array}{l}\text { Panilajuk (B), Kharai } \\
(\mathrm{K})\end{array}$ & Whole plant & Very good tonic & $\begin{array}{l}\text { Given for } 4-12 \text { days } \\
\text { regularly in empty } \\
\text { stomach }\end{array}$ & - & - \\
\hline Ocimum tenuiflorum $\mathrm{L}$. & Lamiaceae & Tulsi (B) & Leaf & Decoction of leaf & $\begin{array}{l}\text { Advice to take } 1-2 \\
\text { tea spoon once in } \\
\text { empty stomach }\end{array}$ & - & - \\
\hline $\begin{array}{l}\text { Oroxylum indicum (L.) Benth. } \\
\text { ex Kurz }\end{array}$ & Bignoniaceae & Tokharung (K) & Bark & Decoction of bark is taken & $\begin{array}{l}\text { Given orally for } \\
\text { some days }\end{array}$ & - & $\begin{array}{l}\text { Must be given in } \\
\text { empty stomach }\end{array}$ \\
\hline Pavetta indica $\mathrm{L}$. & Rubiaceae & - & Root & Root decoction & $\begin{array}{l}\text { Taken twice a day } \\
\text { for } 5-7 \text { days }\end{array}$ & - & - \\
\hline $\begin{array}{l}\text { Phyllanthus niruri Roxb. ex } \\
\text { Wall }\end{array}$ & Euphorbiaceae & Bon amlokhi & $\begin{array}{l}\text { Fruit } \\
\text { Leaf }\end{array}$ & $\begin{array}{l}\text { Fruit is eaten raw } \\
\text { Green leaves are spread over the } \\
\text { infected area for soft feelings }\end{array}$ & Until cure & - & - \\
\hline Plumbago zeylanica $\mathrm{L}$. & Plumbaginaceae & $\begin{array}{l}\text { Chita, Chitra (B), } \\
\text { Jaundicea (S) }\end{array}$ & Leaf, Root & $\begin{array}{l}\text { Leaf juice externally used in jaundice. } \\
\text { Root paste applied on snake bite. } \\
\text { Leaves tied over the wound. }\end{array}$ & - & - & $\begin{array}{l}\text { Juice and paste } \\
\text { must be used } \\
\text { externally }\end{array}$ \\
\hline Saccharum officinarum L. & Poaceae & $\begin{array}{l}\text { Kussar (B) } \\
\text { Kuruk (K) }\end{array}$ & Stem & Stem juice & $\begin{array}{l}\text { It is advised to take } \\
\text { regularly until cure }\end{array}$ & - & - \\
\hline
\end{tabular}




\begin{tabular}{|c|c|c|c|c|c|c|c|}
\hline $\begin{array}{l}\text { Schima wallichii (DC.) } \\
\text { Choisy }\end{array}$ & Theaceae & $\begin{array}{l}\text { Kanak, Makrisal (B), } \\
\text { Chelauni (K) }\end{array}$ & Leaf & $\begin{array}{l}\text { Decoction of the leaf crushed mixture } \\
\text { along with Cassia fistula L. and } \\
\text { Solanum indicum L. }\end{array}$ & $\begin{array}{l}\text { Decoction taken with } \\
\text { little salt }\end{array}$ & $\begin{array}{l}\text { Salt, Cassia fistula } \\
\text { L. (Sonal), } \\
\text { Solanum indicum } \\
\text { L.(Bon begun) }\end{array}$ & - \\
\hline Scoparia dulcis L. & Scrophulariaceae & Naipungchewk (H) & Leaf, twigs & $\begin{array}{l}\text { Extract is taken in empty stomach for a } \\
\text { week }\end{array}$ & - & - & - \\
\hline Smilax zeylanica $\mathrm{L}$. & Smilacaceae & $\begin{array}{l}\text { Komarialata, } \\
\text { Koyargalata, Komarica } \\
\text { (B), Ramlata (S), } \\
\text { Koyarma (K) }\end{array}$ & Root, Leaf & $\begin{array}{l}\text { Mixture of root powder along with bark } \\
\text { powder of Ziziphus oenoplia (L.) } \\
\text { (Banbadai) and Streblus asper (Harka) } \\
\text { used to cure hepatitis, nephritic and } \\
\text { blood dysentery. } \\
\text { Root paste is boiled with goat milk } \\
\text { given for sexual stimulant. } \\
\text { Fresh leaves as fodder for cattle for high } \\
\text { milk production. }\end{array}$ & $\begin{array}{l}\text { Mixture given } \\
\text { regularly in early } \\
\text { morning for } 2 \text { weeks. }\end{array}$ & $\begin{array}{l}\text { Bark of Ziziphus } \\
\text { oenoplia (L.) Mill. } \\
\text { (Banbadai) and } \\
\text { Streblus asper } \\
\text { (Harka) for the } \\
\text { mixture. }\end{array}$ & $\begin{array}{l}\text { Roots and barks } \\
\text { must be dried. } \\
\text { Mixture must be } \\
\text { in the ratio of } \\
3: 2: 1 \text { in a warm } \\
\text { water }\end{array}$ \\
\hline Solanum nigrum $\mathrm{L}$. & Solanaceae & $\begin{array}{l}\text { Kakmachi (B), } \\
\text { Rummunta (H) }\end{array}$ & Root & Powdered roots & $\begin{array}{l}2-3 \text { tea spoon full } \\
\text { mix with water } \\
\text { advice to take at } \\
\text { early morning }\end{array}$ & - & $\begin{array}{l}\text { Must be given } \\
\text { orally }\end{array}$ \\
\hline $\begin{array}{l}\text { Terminalia bellirica } \\
\text { (Gaertn.) Roxb. }\end{array}$ & Combretaceae & Boira $(\mathrm{K})$ & Fruit & $\begin{array}{l}\text { Dried fruit dipped in water at least } 2-3 \\
\text { hours before, then the water is taken. }\end{array}$ & Regularly & - & - \\
\hline Thunbergia grandiflora Roxb. & Acanthaceae & Vako & Root & Root powder taken & Taken twice a day & - & - \\
\hline Tinospora cordifolia Miers & Menispermiaceae & $\begin{array}{l}\text { Paddakuruj, Gulancha, } \\
\text { Ghamacilata (B), } \\
\text { Duksha-sundari (K) }\end{array}$ & Stem & $\begin{array}{l}\text { Stem is cut into small pieces and soaked } \\
\text { and given in empty stomach to cure } \\
\text { diabetic complains. Decoction of stem is } \\
\text { used in liver complains and in } \\
\text { vermifuges. }\end{array}$ & $\begin{array}{l}\text { Soaked stem given in } \\
\text { empty stomach. }\end{array}$ & - & $\begin{array}{l}\text { Soaked in a glass } \\
\text { of water } \\
\text { overnight }\end{array}$ \\
\hline $\begin{array}{l}\text { Typhonium trilobatum (L.) } \\
\text { Schott }\end{array}$ & Araceae & Kharkun (B) & Leaf & $\begin{array}{l}\text { Leaves are used as vegetable and taken } \\
\text { regularly with the meal }\end{array}$ & - & - & - \\
\hline $\begin{array}{l}\text { Vanda tessellata Hook. ex G. } \\
\text { Don }\end{array}$ & Orchidaceae & $\begin{array}{l}\text { Orchid, Rashna (B), } \\
\text { Khumchuk (K) }\end{array}$ & Leaf & $\begin{array}{l}\text { Mixture of the crushed leaf, along with } \\
\text { root of Carica papaya L., Allophylus } \\
\text { racemosus Sw. and little amount of } \\
\text { snail flesh, few garlic and black pepper } \\
\text { and small pills are made. }\end{array}$ & $\begin{array}{l}\text { Pills to be taken in } 2 \\
\text { hours for a week to } \\
\text { cure jaundice }\end{array}$ & $\begin{array}{l}\text { Carica papaya } \mathrm{L} . \\
\text { (Pepe), Allophylus } \\
\text { racemosus Sw. } \\
\text { (Choanti), snail } \\
\text { flesh, garlic, black } \\
\text { pepper }\end{array}$ & - \\
\hline Ziziphus oenoplia (L.) Mill. & Rhamnaceae & $\begin{array}{l}\text { Chiyakul, Bonbaroi } \\
\text { (B), Brui, } \\
\text { Chiyangbufang (S/ (K) }\end{array}$ & Bark & $\begin{array}{l}\text { Grinded bark is taken } 2 \text { to } 3 \text { spoons } \\
\text { daily with water. }\end{array}$ & - & - & $\begin{array}{l}\text { Decoction of the } \\
\text { bark must be } \\
\text { taken and dry } \\
\text { fruit can be used. }\end{array}$ \\
\hline
\end{tabular}


Table 2: Enumeration of the recorded plant species used in jaundice with their active chemical constituents as reported by different workers

Species

Allium sativum L.

Allophylus racemosus $\mathrm{Sw}$.

Alocasia indica (Roxb.) Schott.

Andrographis paniculata (Burm. f.) Wall. ex Nees

Asteracantha longifolia Nees.

Averrhoa carambola $\mathrm{L}$.

Azadirachta indica $\mathrm{L}$.

Bacopa monnieri (L.) Pennell

Cajanus cajan (L.) Millsp.

Carica papaya $\mathrm{L}$.

Cassia fistula $\mathrm{L}$

Centella asiatica (L.) Urb

\section{Active chemical constituents}

Alanine, allicin, alliin, alliinase, allistatin-i, allistatin-ii, allixin, allyl-disulfide, allyl-methyl-disulfide, allyl-methyl-trisulfide, allyl-alpha-tocopherol, aniline; arachidonic-acid, arginine; beta-phellandrene, beta-tocopherol, biotin; caffeic-acid, choline, cis-ajoene, citral, cycloalliin, cystine, desgalactotigonin, gitonin, glutathione, glycerol-sulfoquinovoside, glycine, histidine, isobutyl-isothiocyanate, isoleucine, leucine, linalol, lysine, methionine, nicotinic-acid, p-coumaric-acid, phenylalanine, phosphatidyl-choline, phosphatidyl-ethanolamine, phosphatidyl-inositol, phosphatidyl-serine, proline, propene, propenethiol, scorodinin, scorodose, serine; thiamacornine, thiamamidine, threonine, tryptophan, tyrosinase, tyrosine, valine (http://www.mdidea.com/products/new/new00106.html).

$\beta$-sitosterol, phenacetamide, a chemical known for its antiulcer activity, flavonoid glycosides that are effective against ulcer (Rastogi and Mehrotra 1995).

Protein, carbohydrate, ascorbic acid, alpha-tocopherol, nitric oxide, malonaldehyde, alkaloids, tannins, glycosides, saponins, flavonoids, $\beta$-hydroxyque brachamine, 10-dicarboxylic acid, 2, $4 \alpha$-dihydroxy-1-methyl-8 methylene, $14 \alpha$-lactone, 1,2-benzenedicarboxylic acid, 9-hexadecenoic acid, dodecanoic acid, linoleic acid and its ester, oleic acid, ethyl oleate (Pal et al. 2014).

Andrographolide, 14-deoxy-11-oxoandrographolide, 14-deoxy-11, 12-didehydroandropgrapholide, 14-deoxyandropgrapholide, neoandrographolide, andrographosterol, andrographane, andrographone, andrographosterin, andrograpanin, $\alpha$-sitosterol, stigmasterol, andrographin, monohydroxy trimethyl flavones, dihydroxy-di-methoxyflavone, panicolin, andrographoneo, andrographoside, andropaniculosin A, andropani-culoside A (Niranjan et al. 2010; Hossain et al. 2014)

Phytosterols, fatty acids, minerals, polyphenols, proanthocyanins, alkaloids, enzymes, carbohydrates, flavonoids, terpenoids, vitamins (Doss and Anand 2014)

Ascorbic acid, protein, polyphenol oxidase, proanthocyanidins, epicatechin (Gheewala et al. 2012).

Protein, Crude fibre, Fat, Manganese, Selenium, Zinc, Iron, Copper, Magnesium, Chromium, Flavonoids, Tannins, Saponins, Polyphenol, Alkaloids (Atangwho et al. 2009).

Baco saponin (A, B, C and D) (Srivastava et al. 2009).

Protein, amino acid, steroid, phenolic compound (Mohanty and Chourasia 2011).

Protein, fat, fibre, carbohydrates, calcium, phosphorus, iron, vitamin $\mathrm{C}$, thiamine, riboflavin, niacin, caroxene, amino acid, citric acids, molic acid (green fruits), volatile compounds: linalol, benzylisothiocynate, cis and trans 2, 6-dimethyl-3,6 expoxy-7 octen-2-ol. Alkaloid, $\alpha$; carpaine, benzyl- $\beta$-d glucoside, 2 -phenylethl- $\beta$-d-glucoside, 4-hydroxyl-phenyl-2 ethyl-b-d glucoside and four isomeric malonated benzyl- $\beta$-d glucosides (Nadkarni 1954; Bruneton et al. 1999).

Procyanidin $\mathrm{B}_{2}$, biflavonoids, triflavonoids, rhein, rhein glucoside, sennoside (A \& B), chrysophanol, physcion (Kaji et al. 1968; Mahesh et al. 1984; Kashiwada et al. 1996).

Asiatic acid, madecassic acid, asiaticoside, madecassoside, madasiatic acid, betulinic acid, thankunic acid, isothankunic acid (Orhan 2012); Flavonoid derivative s such as quercetin, kaempferol, patuletin, rutin, apigenin, castilliferol, castillicetin, and myricetin (Kuroda et al. 2001; Matsuda et al. 2001); centellose (Wang et al. 2014); cadinol, acetoxycentellinol, centellin, centellicin, and asiaticin (Siddiqui et al. 2007) sterols (Rumalla et al. 2010); phenolic acids (Yoshida et al. 2005). 
Citrus limon (L.) Osbeck

Citrus medica $\mathrm{L}$

Coccinia grandis (L.) Voigt

Cocos nucifera $\mathrm{L}$.

Costus speciosus (J. Koenig) Sm.

Cuscuta reflexa Roxb.

Enhydra fluctuans Lour.

Ensete glaucum (Roxb.) Cheesm

Entada phaseoloides (L.) Merr.

Garcinia pedunculata Roxb. Ex Buch.-Ham

Glycosmis arborea (Roxb.) DC.

Hibiscus surattensis $\mathrm{L}$.

Ichnocarpus frutescens (L.) R. Br

Ipomoea aquatica Forssk.

Mangifera indica $\mathrm{L}$.

Marsilea minuta L.

Micromelum integerrimum (Roxb. ex DC.) Wight Arn. ex M. Roem.

Momordica charantia $\mathrm{L}$.

Moringa oleifera L.
Cymene, E-citral, DL-limonene, L- $\alpha$-terpineol, $\beta$-pinene, $\alpha$-terpinolene, terpinen-4-ol (Al-Jabri and Hossain 2014)

Alkaloids, flavonoids, phenols, carbohydrates, glycosides (Negi et al. 2011)

Sterols, tannins, flavonoids, proteins, amino acids, glycosides, phenols, saponins, alkaloids (Umamaheswari and Chatterjee 2008)

Protein, total lipid (fat), carbohydrate, fiber, sucrose, glucose, fructose, mannitol, sorbitol, myo-inositol, scyllo-inositol (Yong et al. 2009

Carbohydrates, vitamin C, vitamin E, flavonoids, phenols, glycosides, saponins, alkaloids and minerals like Zinc, Copper, Manganese, Selnenium and Iron (Jagtap and Satpute 2014).

Scoparone, melanettin, quercetin, hyperoside, phenolic compounds, caffeoylquinic acids (Prajapati et al. 2006)

Sesquiterpene lactones (Husain 1992)

The chemical constituents is not reported earlier for its root parts

Entada saponin (ES)-III (Okada et al 1987), chalcone glycosides 4'- $O$-(6"-O-galloyl- $\beta$-D-glucopyranosyl)-2',4-dihydroxychalcone; 4'- $O$-(6"- $O$-galloyl- $\beta$ D-glucopyranosyl)-2'-hydroxy-4-methoxychalcone; 4'- $O$ - $\beta$-D-glucopyranosyl-2'-hydroxy-4-methoxychalcone (Zhao et al. 2011)

Protein, $\beta$ carotene ,thiamine, riboflavin, ascorbic acid, calcium, phosphorus, magnesium, iron, sodium, potassium, copper, zinc, calcium (Islam et al. 2015)

Carbazole alkaloids, glybomines (A, B and C), arborinine, arborine (Ito et al. 2004)

Monoterpenes, sesquiterpene compounds, $\beta$-caryophyllene, menthol, methyl salicylate, camphor, germacrene $\mathrm{D}$, hexadecanoic acid, $\alpha$-humulene, 1,8 cineole, menthone (Ogundajo et al. 2014).

Flavonoids, polyphenols, anthocyanins and simple phenolic acids (Kumarappan et al.2012)

Protein, ash, fiber ,fat, iron, magnesium, calcium, phosphate, manganese, sulphate, nitrates, vitamins (A, B1, C and K), alkaloids, flavonoids, steroids, phenols, glycosides, $\beta$-carotene, saponins and tannins (Igwenyi et al. 2011)

Mangiferin (Nong et al. 2005); steroids, flavonoid, reducing sugar and cardiac glycosides anthraquinone, tannin ( Aiyelaagbe and Osamudiamen 2009)

Sodium, potassium, calcium, phosphorus, protein, $\beta$-carotene (Dewanji et al. 1993)

Coumarins as microintegerrin A, microintegerrin B, scopoletin, scopolin of leaf and bark. But chemical constituent is not available from roots (Wang et al. 2014)

Glycosides, saponins, alkaloids, fixed oils, triterpenes, proteins and steroids (Raman and Lau 1996; http://www.raintree.com/bitmelon.htm), Vitamin C, Vitamin A, phosphorus and iron (http://momordica.allbio.org/). Several phytochemicals have been isolated such as momorcharins, momordenol, momordicilin, momordicins, momordicinin, momordin, momordolol, charantin, charine, cryptoxanthin, cucurbitins, cucurbitacins, cucurbitanes, cycloartenols, diosgenin, elaeostearic acids, erythrodiol, galacturonic acids, gentisic acid, goyaglycosides, goyasaponins, multiflorenol (Husain et al. 1994; Xie et al. 1998; Yuan et al. 1999; Parkash et al. 2002). These are reported in all parts of the plant (Murakami et al. 2001).

Linalool, $\alpha$-terpineol, p-vinylguaiacol, cis-dihydroagarofuran, eudesm-11-en-4- $\alpha, 6 \alpha$-diol, 1-octadecene, octadecane, 5-octadecin, n-hexadecanol, 1eicosene, eicosane, n-octadecanol, heneicosane, cyclopentadecanol, 1-docosene, docosane, cis-9-eicosen-1-ol, tricosane, tetracosane, pentacosane, hexacosane, heptacosane, octacosane, nonacosane, triacontane, hexenyl propanoate, phenylethyl alcohol, pseudo phytol (Marrufo et al. 2013); calcium, magnesium, potassium, sodium, iron, zinc, copper (Valdez-Solana et al. 2015) 
Neptunia prostrata Baill.

Ocimum tenuiflorum $\mathrm{L}$.

Oroxylum indicum (L.) Benth. ex Kurz

Pavetta indica $\mathrm{L}$.

Phyllanthus niruri Roxb. ex Wall

Piper longum $\mathrm{L}$.

Plumbago zeylanica $\mathrm{L}$.

Saccharum officinarum $\mathrm{L}$.

Schima wallichii (DC.) Choisy

Scoparia dulcis L.

Smilax zeylanica $\mathrm{L}$.

Solanum nigrum $\mathrm{L}$.

Terminalia bellirica (Gaertn.) Roxb.

Thunbergia grandiflora Roxb.

Tinospora cordifolia Miers

Typhonium trilobatum (L.) Schott

Vanda tessellata Hook. ex G. Don

Zingiber officinale $\mathrm{L}$.

Ziziphus oenoplia (L.) Mill.
Glycosides, flavonoids, tannins, steroids, terpenoids, carbohydrate, protein, fat (Deb et al. 2013)

Tannins, alkaloid, terpenoids, flavonoids, phlobatannins, glycosides, morphine, boldine, saponin, phlobatannins, steroid, ascorbic acid, carotenoids, phenols (Palla et al. 2012)

Baicalein (5,6,7-trihydroxyflavone) [Derivatives: Baicalein 6-glucuronide, baicalein 7-glucuronide, baicalein 7-0- $\beta$-gentiobioside, tetulin (6-glucoside of baicalein), 8,8"-bisbaicalein 1, baicalein-7-o-caffeate 2], oroxylin-a (5,7-dihydroxy-6-methoxyflavone), chrysin (5,7-dihydroxyflavone) (Raghu et al. 2013)

Tricyclin, benzaldehyde, sabinine, limonine, acetophenone, linalool, perilline, thujupsa-3-one, $\beta$-carryophylene, $\beta$-edudesmole, $\beta$-pinene, $\alpha$ terpenene, $\alpha$ humulene, $\alpha$-guaiene (Prasad et al. 2010)

Phyllanthine, hypophyllanthine, flavonoids, quercetin, astralgin, quercitrin, isoquercitrin, rutine, alkaloids (Prajapati et al. 2006).

Piperine, piplatin, piperlongumine, piperlonguminine, methyl-3,4,5-trimehoxycinnamate, guineensine, pipernonaline, pellitonine, piperanine (Mishra 2010; Chouhan et al. 2011)

Plambagin, fatty acids and esters : palmitic acid,-essella acid (Do and Nguyen 1996), terpenoids (Gupta et al. 1998), taraxasterol (Rai et al. 2000), stigmasterol (Nile and Khobragade 2010), stigmasterol acetate, sitosterone (Gupta et al. 1995).

Abscisic acid, apigenin, glycoside, methyl lapigenin, arabinose, arunodin, benzoic acid, campesterol, coumarin, cylindrin, orientin, fructose, glactose, glucose, phytosterol, saccharans, schaftoside, sucrose, invert sugar, ether, tricin and vicenin (Prajapati et al. 2006).

Alkaloids, flavonoids, cardiac glycosides, saponins, tannin, flobatannin (Lalrinzuali et al. 2015).

Alkaloid, Tannin, Carbohydrate, Glycoside (Zulfiker et al. 2010)

Alkaloid, polysterol, phenol, tannin, saponin, flavonoid, protein, amino acid (Madhavan et al. 2008).

Alkaloids, saponins, terpenoids (Gogoi and Islam 2013; Djaafar et al. 2014).

Glycosides, flavonoids, tannins, phenols, saponins, diterpenes, proteins, amino acids (Abraham et al. 2014).

Not reported for its root pharmacognosical analysis.

Proteins, carbohydrates, phenols/tannins, flavonoids, saponins, glycosides, steroids, terpenoids and alkaloids (Agarwala and Yadav 2011)

Flavanoids, alkaloids, saponins and tannins (Roy et al. 2012)

Terpenoids, flavonoids, phenols, alkaloids, tannins, steroids, glycosides (Bhattacharjee et al. 2015).

Protein, calcium, fat, phosphorous, polyphenols, soluble fibre, tannin, flavonoids insoluble fibre, zinc, carbohydrate, copper, vitamin c, manganese, carotenoids, chromium (Shirin and Prakash 2010).

Alkaloids, 7a-hydroxy-6-isopropenyl-3,3,3a,5,6a,10,10-11b,octamethyl-hexadecahydro-benzo[de]anthracene; 5-carboxylic acid identified from root bark (Prabhavathi and Vijayalakshmi 2015). 
constituents. Therefore, proper and intensive inventorying of medicinal plants specific to certain health problems becomes necessary. The diminishing pattern of the knowledge system is in danger leading to more in-depth study across the genders and age to know the transfer system. It is necessary to carry the ethnobotanical study of these plants which would help in the preservation of their knowledge and can be utilized in the conservation of these potential plants. It however requires detail work initiated with inter-cultural study and representing about the status and usage of the same species in curing different ailments coupled with chemical analysis. In this context, activities of phytochemical against jaundice may forward an interesting theme for the future studies to screen out and testing their explicit function. Furthermore, pharmacologicalethnobotanical index of such plants may ascribe the indigenous community's knowledge to higher rates of validation that logically support erosion of traditional knowledge which really needs to be revitalized.

\section{ACKNOWLEDGMENTS}

Financial support for this work was received through Bioresource network Project (No. BT/29/NE/2011) from the Department of Biotechnology (DBT), Government of India, New Delhi. Special thanks to Dr. Kaushik Majumdar for his encouragement and motivation. The authors are grateful to all the ethnic informants of different communities for their active participation and knowledge sharing during the field investigations. Abhijit Sarkar and Mantush Roy are also acknowledged and appreciated for their assistance in field work. The authors also extend their in-depth gratitude to all the anonymous reviewers for their constructive analytical comments.

\section{REFERENCES}

Abbasi AM, Khan MA, Ahmad M, Zafar M, Khan H, Muhammad N, et al. 2009. Medicinal plants used for the treatment of jaundice and hepatitis based on socio-economic documentation. African J Biotechnol 8 (8): 1643-1650.

Abraham A, Mathew L, Samuel S. 2014. Pharmacognostic studies of the fruits of Terminalia bellirica (Gaertn.) Roxb. J Pharmacogn Phytochem 3 (2): 45-52.

Agarwala M, Yadav RNS. 2011. Phytochemical analysis of some medicinal plants. J Phytol 3 (12): 10-14.

Aiyelaagbe OO, Osamudiamen PM. 2009. Phytochemical Screening for Active compounds in Mangifera indica leaves from Ibadan, Oyo State. Plant Sci Res 2 (1): 11-13.

Al-Jabri NN, Hossain MA. 2014. Comparative chemical composition and antimicrobial activity study of essential oils from two imported lemon fruits samples against pathogenic bacteria. Beni-Suef Univ J Basic Appl Sci 3(4): 247-253.

Annalakshmi R, Uma R, Chandran GS, Muneeswaran A. 2012. Common plants used in the treatment of jaundice in southern India as a natural remefier-A review. Indian J Drugs Dis 1 (2): 47-50.

Atangwho IJ, Ebong PE, Eyong EU, Williams IO, Eteng MU, Egbung GE. 2009. Comparative chemical composition of leaves of some antidiabetic medicinal plants: Azadirachta indica, Vernonia amygdalina and Gongronema latifolium. African J Biotechnol 8 (18): 4685-4689.

Bhattacharjee B, Islam T, Rahman Z, Islam SMS. 2015. Antimicrobial activity and phytochemical screening of whole plant extracts of
Vanda tessellata (Roxb.) Hook. ex. G. Don. World J Pharm Pharmaceut Sci 4 (1): 72-83.

Bhattacharya UC, Goel AK. 1981. A note on some plants found effective in treatment of jaundice (Hepatitis). J Econ Tax Bot 2: 157-159.

Bora A, Devi P, Borthakur SK. 2012. Phyto-remedies of jaundice-A traditional approach on Majuli, Special reference to Satra culture people, Assam. Asian J Plant Sci Res 2 (6): 664-669.

Bruneton J. 1999. Carica papaya. In Bruneton J (ed.). Pharmacognosy, Phytochemistry of Medicinal Plants. Tech Doc, Paris 2: 221-223.

Burtis CA, Ashwood ER. 2003. Tietz Fundamentals of Clinical Chemistry. 5th ed. Elsevier, New Delhi.

Choudhury S, Sharma P, Dutta Choudhury M, Dutt Sharma G. 2012. Ethnomedicinal plants used by Chorei tribes of Southern Assam, North Eastern India. Asian Pac J Trop Dis 2 (1):141-147.

Chouhan K, Solanki R, Patel A, Macwan C, Patel M. 2011. Phytochemical and therapeutic potentrial of Piper longum Linn.: a review. Intl J Res Ayurveda Pharm 2 (1): 157-161.

Das HB, Majumdar K, Datta BK, Ray D. 2009. Ethnobotanical uses of some plants by Tripuri and Reang tribes of Tripura. Nat Prod Radiance 8 (2): 172-180.

Das S, Choudhury MD. 2010. Plants used against gastro-intestinal disorders and as anti hemorrhagic by three tribes of North Tripura District, Tripura, India. Ethnobot Leafl 14: 467-478.

Das S, Choudhury MD. 2012. Ethnomedicinal uses of some traditional medicinal plants found in Tripura, India. J Med Pl Res 6 (35): 49084914

Das S, Dutta Choudhury M, Mandal SC, Das Talukdar A. 2012. Traditional knowledge of ethnomedicinal hepatoprotective plants used by certain ethnic communities of Tripura state. Indian $\mathbf{J}$ Fundament Appl Life Sci 2 (1): 84-97.

Das S, Dutta Choudhury M. 2012. Ethnomedicinal uses of some traditional medicinal plants found in Tripura, India. J Med. Pl Res 6 (35): 4908-4914.

Das S, Sarma G, Barman S. 2008. Hepatoprotective activity of aqueous extract of fruit pulp of Cassia fistula (AFCF) against carbon tetrachloride $(\mathrm{CCl} 4)$ induced liver damage in albino rats. J Clin and Diagn Res 2: 1133-1139.

Das T, Mishra SB, Saha D, Agarwal S. 2012. Ethnobotanical survey of medicinal plants used by ethnic and rural people in Eastern Sikkim Himalayan region. African J Basic Appl Sci 4 (1): 16-20.

De B, Debbarma T, Sen S, Chakraborty R. 2010. Tribal life in the environment and biodiversity of Tripura, India. Curr World Environ 5:59-66.

Deb D, Darlong L, Sarkar A, Roy M, Datta BK. 2012. Traditional ethnomedicinal plants use by the Darlong tribes in Tripura, Northeast India. Intl J Ayurvedic Herbal Med 2 (6): 954-966.

Deb DB. 1968. Medicinal plants of Tripura State. Indian For 94 (10): 753 765.

Deb DB. 1981. Flora of Tripura State. Vol. I. Today and Tomorrow Printers and Publisher, New Delhi.

Deb DB. 1983. Flora of Tripura State. Vol. II. Today and Tomorrow Printers and Publisher, New Delhi.

Deb PK, Das S, Nath Bhaumik K, Ghosh R, Ghosh TK, Bhakta T. 2013. Pharmacognostic \& preliminary phytochemical investigations of Neptunia prostrata L. J Pharmacogn Phytochem 2 (3): 5-11.

Dewanji S, Matai L, Barik S SI, Nag A. 1993. Chemical composition of two semi-aquatic plants for food use. Pl Foods Human Nutr 44:11-16.

Djaafar Z, Ridha Ouahrani M. 2014. Phytochemical study of selected Medicinal plant, Solanum nigrum, the Algerian Desert. Intl Lett Chem Phys Astron 20: 25-30.

Do DR, Nguyen XD. 1996. Chemical constituents of Plumbago zeylanica Linn. Tap Chi Hoa Hoc 34: 67-70.

Doss A, Anand SP. 2014. Evaluation of anti-diabetic activity of methanol and aqueous extracts of Asteracantha longifolia (Linn.) Nees. J Pharmacol 8 (1): 1-5.

Dutta U, Sarma GC. 2013. Medicinal plants used by the local fringe communities of Chirang Reserve Forest, BTAD, Assam. Indian J Res 2 (2): 262-265.

Gheewala P, Kalaria P, Chakraborty M, Kamath JV. 2012. Phytochemical and Pharmacological profile of Averrhoa carambola Linn: An overview. Int Res J Pharm 3: 88-92.

Mohanty PK, Chourasia N. 2011. Preliminary phytochemical screening of Cajanus cajan Linn. Asian J Pharmaceut Technol 1 (2): 49-52.

Gogoi P, Islam M. 2012. Ethnomedicinal Study of Solanum nigrum L, and 
S. myriacanthus Dunal used by tribals and non-tribals from Districts of Upper Assam, India. Asian J Exp Bio Sci 3 (1): 73-81.

Gupta A, Rai R, Siddiqui IR, Singh J. 1998. Two new triterpenoids from Plumbago zeylanica. Fitoterapia 69: 420-422.

Gupta MM, Verma RK, Gupta AP. 1995. A chemical investigation of Plumbago zeylanica. Curr Res Med Aromather Plants 17:161-164.

Guyton A, Hall J. 2005. Textbook of Medicinal Physiology. WB. Saunders, Philladelphia.

Hossain MS, Urbi Z, Sule A, Rahman KMH. 2014. Andrographis paniculata (Burm. f.) Wall. ex Nees: A review of ethnobotany, phytochemistry, and pharmacology. Sci World J 2014: 1-28.

Husain A. 1992. Dictionary of Indian Medicinal Plants. Central Institute of Medicinal and Aromatic Plants, Lucknow.

Husain J, Tickle IJ, Wood SP. 1994. Crystal structure of momordin, a type I ribosome inactivating protein from the seeds of Momordica charantia. FEBS Lett 342: 154-158.

Igwenyi IO, Offor CE, Ajah DA, Nwankwo OC, Ukaomah JI, Aja PM 2011. Chemical compositions of Ipomoea aquatica (green kangkong). Intl J Pharm Biol Sci 2 (4): 593-598.

Islam MZ, Hoque MM, Asif-Ul-Alam SM, Monalisa K. 2015. Chemica composition, Antioxidant capacities and storage stability of Citrus macroptera and Garcinia pedunculata fruits. Emir J Food Agric 27 (3): $275-282$

Ito C, Itoigawa M, Sato A, Hasan Choudhury M, Mohammad RA, Tokuda H, Mukainaka T, Nishino H, Furukawa H. 2004. Chemical constituents of Glycosmis arborea: Three new carbazole alkaloids and their biological activity. J Nat Prod 67: 1488-1491.

Jagtap S, Satpute R. 2014. Phytochemical screening and antioxidan activity of rhizome extracts of Costus speciosus (Koen.) J.E. Smith. J Artif Intell Res 3 (1): 40-47.

Jayachandra K, Devi VS. 2012. Development of herbal drugs in the treatment of jaundice-An overview. Intl J Ayurvedic Herb Med 2 (4): 636-645.

Kaji NN, Khorana ML, Sanghavi MM. 1968. Studies on Cassia fistula Linn. Indian J Pharm 30: 8-11.

Kala CP. 2005. Ethnomedicinal botany of the Apatani in the Eastern Himalayan region of India. J Ethnobiol Ethnomed 1: 11-18.

Karmakar P, Islam MM, Kibria MG, Hossain MS, Sattar MM. 2012. Prevalence, belief and awareness of preferring traditional health care system in urban and rural people of Noakhali district, Bangladesh. Int Curr Pharm J 1 (9): 229-234.

Karuppasmy S. 2007. Medicinal plants used by Paliyan tribes of Sirumalai hills of southern India. Nat Prod Radiance 6 (5): 436-442.

Kashiwada Y, Toshika K, Chen R, Nonaka G, Nishioka I. 1996. Tannins and related compounds. XCIII. Occurrence of enantiomeric proanthocyanidins in the Leguminosae plants, Cassia fistula L. Cassia javanica L. Chem Pharm Bull 38: 888-893.

Kumarappan CT, Thilagam E, Mandal SC. 2012. Antioxidant activity of polyphenolic extracts of Ichnocarpus frutescens. Saudi J Biol Sci 19 (3):349-55. doi: 10.1016/j.sjbs.2012.04.004

Kuroda M, Mimaki Y, Harada H, Sakagami H, Sashida Y. 2001. Five new triterpene glycosides from Centella asiatica. Nat Med 55 (3): 134 138.

Lalrinzuali K, Vabeiryureilai M and Ganesh Chandra J. 2015. Ethnomedicinal use and phytochemical analysis of selected medicinal plants of Mizoram, India. Trends Green Chem 1 (8): 1-9.

Lokho A. 2012. The folk medicinal plants of the Mao Naga in Manipur, North East India. Intl J Sci Res Publ 2 (6): 1-8.

Madhavan V, Hemalatha HT, Murali A, Yoganarasimhan SN. 2008 Antiepileptic activity of alcohol and aqueous extracts of roots and rhizomes of Smilax zeylanica Linn. Pharmacologyonline 3: 263-272.

Mahesh VK, Sharma R, Singh RS 1984. Anthraquinones and kaempferol from Cassia fistula species. J Nat Prod 47: 733-751.

Majumdar K, Datta BK. 2007. A study on ethnomedicinal usage of plants among the folklore herbalists and Tripuri medical practitioners: PartII. Indian J Nat Prod Resour 6 (1): 66-73.

Majumdar K, Saha R, Datta BK, Bhakta T. 2006. Medicinal plants prescribed by different tribal and non-tribal medicine man of Tripura State. Indian J Trad Know 5 (4): 559-562.

Manikandan K, Rajendran K, Shanmugam S. 2009. Ethnomedicinal survey of medicinal plants for the treatment of diabetes \& jaundice among the villagers of Sivagangai district Tamil nadu. J Ethnobot Leafl 13:189-94.

Marrufo T, Nazzaro F, Mancini E, Fratianni F, Coppola R, De Martino L et al. 2013. Chemical composition and biological activity of the essential oil from leaves of Moringa oleifera Lam. cultivated in
Mozambique. Molecules 10.3390/molecules 180910989

Matsuda H, Morikawa T, Ueda H, Yoshikawa M. 2001. Medicinal foodstuffs. XXVII. Saponin constituents of gotu kola (2): structures of new ursane-and oleanane-type triterpene oligoglycosides, centellasaponins B, C, and D, from Centella asiatica cultivated in Sri Lanka. Chem Pharm Bull 49 (10):1368-1371.

Mayes PA. 2000. Harpers Biochemistry, 25 ${ }^{\text {th }}$ ed. McGraw Hill, New York

Mishra D, Singh RK, Srivastava RK. 2012. Ethno-medicinal plants used to cure different diseases by rural folks and tribes of North Eastern Tarai districts of Uttar Pradesh, India. Res J Med Plants 6 (4): 286299.

Mishra P. 2010. Isolation, spectroscopic characterization and computational modeling of chemical constituents of Piper longum natural product. Intl J Pharm Sci Rev Res 2 (2): 78-86.

Monsen ER. 2000. Dietary reference intake for antioxidant nutrients. J Am Diet Assoc 100: 637-640.

Murakami T, Emoto A, Matsuda H, Yoshikawa M. 2001. Medicinal foodstuffs. Part XXI. Structures of new cucurbitane-type triterpene glycosides, goyaglycosides-a,-b,-c,-d,-e,-f,-g, and-h and new oleanane-type triterpen saponins, goyasaponins I, II, and III, from the fresh fruit of Japanese Momordica charantia L. Chem Pharm Bull 49: 54-63.

Nadkarni KM. 1954. Indian material medica. Pop Pra Pvt Ltd, Bombay 1: 273-277.

Negi A, Joshi A, Juyal V, Kumar T. 2011. Antidiabetic and Hypolipidemic Activity of Citrus medica Linn. seed extract in streptozotocin induced diabetic rats. Pharmacog J 23 (12): 80-84.

Nile SH, Khobragade CN. 2010. Antioxidant activity and flavonoid derivatives of Plumbago zeylanica. J Nat Prod 3: 130-133.

Niranjan A, Tiwari SK, Lehri A. 2010. Biological activities of kalmegh (Andrographis paniculata Nees) and its active principles-a review. Indian J Nat Prod Resour 1 (2): 125-135.

Ogundajo AL, Ogunwande IA, Bolarinwa TM, Joseph OR, Flamini G. 2014. Essential oil of the leaves of Hibiscus surattensis L. from Nigeria. J Essent Oil Res 26 (2): 114-117.

Okada Y, Shibata S, Ikekaw T, Ana MJJ, Kamo O. 1987. Entada saponinIII, a saponin isolated from the bark of Entada phaseoloides. Phytochem 26 (10): 2789-2796.

Okuda T, Yoshiba T, Hatano T. 1991. Chemistry and biological activities of tannins in medicinal plants. J Sci Technol 5: 127-301.

Okwu DE, Ndu CU. 2006. Evaluation of the phytonutrients, mineral and vitamin contents of some varieties of yam. Intl J Mol Med Adv Sci 12 (2): 199-203.

Orhan IE. 2012. Centella asiatica (L.) Urban: from traditional medicine to modern medicine with neuroprotective potential. Hindawi Publishing Corporation 1-8. doi:10.1155/2012/946259

Pal S, Bhattacharjee A, Mukherjee S, Bhattacharya K, Khowala S. 2014. Antioxidant and hepatoprotective activity of ethanolic extract of Alocasia indica Tuber. Amer J Phytomed Clin Therapeut 2 (2): 191208.

Palla R, Elumalai A, Eswaraiah MC, Kasarla R. 2012. A review on krishna tulsi, Ocimum tenuiflorum Linn. Intl J Res Ayurveda Pharm 3 (2): 291-293.

Parkash A, Ng TB, Tso WW. 2002. Purification and characterization of charantin, a napin-like ribosome-inactivating peptide from bitter gourd (Momordica charantia) seeds. J Peptide Res 59: 197-202.

Prabhavathi S, Vijayalakshmi S. 2015. New hydroxy carboxylic acid from the root bark of Ziziphus oenoplia. J Pharmacog Phytochem 3 (6): $150-152$.

Prajapati ND, Purohit SS, Sharma AK, Kumar T. 2006. A Hand book of Medicinal Plants. 3rd edition. Agrobios Hindustan Printing Press, Jodhpur.

Prasad K, Moulekhi K, Bisht G. 2010. Chemical composition of the essential oils of Pavetta indica leaves. Res J Phytochem 2010: 1-4.

Raghu AV, George S, Krishna VR, Sindhu KK. 2013. Bioactive properties of phenolics present in Oroxylum indicum-A review. J Pharmacog Phytochem 2 (3): 23-27.

Rahim ZB, Rahman MM, Saha D, Hose SMZ, Paul S, Kader S. 2012. Ethnomedicinal plants used against jaundice in Bangladesh and its economical prospects. Bull Pharm Res 2 (2): 91-105.

Rai MK, Pandey AK, Acharya D. 2000. Ethno-medicinal plants used by Gond tribe of Bhanadehi, district Chhindwara, Madhya Pradesh. J Non-timber For Prod 7: 237-241.

Rai PK, Lalramnhinglova H. 2010. Lesser known ethnomedicinal plants 
of Mizoram, North East India: An Indo-Burma hotspot region. J Med Pl Res 4 (13): 1301-1307.

Raman A, Lau C. 1996. Anti-diabetic properties and phytochemistry of Momordica charantia L. (Cucurbitaceae). Phytomed 2: 349-362.

Rastogi RP, Mehrotra BN. 1995. Compendium of Indian Medicinal Plants. Vol 4. Publication and Information Directorate, New Delhi.

Roy SK, Mishra PK, Nandy S, Datta R, Chakroborty B. 2012. Potential wound healing activity of the different extract of Typhonium trilobatum in albino rats. Asian J Trop Biomed 2 (3): 1477-1486.

Rumalla CS, Ali Z, Weerasooriya AD, Smillie TJ, Khan IA. 2010. Two new triterpene glycosides from Centella asiatica. Planta Medica 76 (10): 1018-1021.

Sahu C, Pattnaik SK, Sahoo SL, Lenka SS, Dhal NK. 2011. Ethnobotanical study of medicinal plants in the coastal districts of Odisha. Curr Bot 2 (7): 17-20.

Sajem A, Gosai K. 2008. Ethnobotanical investigations among the Lusai tribes in North Cachar Hills district of Assam, Northeast India. Indian J Trad Know 9 (1): 108-113.

Sen S, Chakraborty R, De B, Devanna N. 2011. An ethnobotanical survey of medicinal plants used by ethnic people in West and South district of Tripura, India. J For Res 22 (3): 417-426.

Shankar R, Rawat MS, Majumdar R, Baruah D, Bharali BK. 2012. Medicinal plants used in traditional medicine in Mizoram. World J Sci Technol 2 (12): 42-45.

Shil S, Choudhury MD. 2009. Ethnomedicinal importance of Pteridophytes used by Reang tribe of Tripura, North East India. Ethnobot Leaflet 13: 634-643.

Shirin APR, Prakash J. 2010. Chemical composition and antioxidant properties of ginger root (Zingiber officinale). J Med Plants Res 4 (24): 2674-2679.

Siddiqui BS, Aslam H, Ali ST, Khan S, Begum S. 2007. Chemical constituents of Centella asiatica. J Asian Nat Prod Res 9 (4): 407414

Sikdar M, Dutta U. 2008. Traditional phytotherapy among the Nath People of Assam. Ethno-Med 2 (1): 39-45.

Singh HB, Hynniewta TM, Bora PJ. 1997. Ethno-Medico-Botanical studies in Tripura, India. Ethnobot 9: 56-58.

Srivastava S , Mishra N , Misra U. 2009. Bacopa monniera-a future perspective. Intl J Pharm Sci Drug Res 1 (3): 154-157.

Umamaheswari M, Chatterjee TK. 2008. In vitro antioxidant activities of the fractions of Coccinia grandis leaf extract. African J Trad Compl Altern Med 5 (1): 61-73.

Valdez-Solana MA, Mejía-García VY, Alfredo TV, Guadalupe GA, José SP, et al. 2015. Nutritional content and elemental and phytochemical analyses of Moringa oleifera grown in Mexico. J Chem. http://dx.doi.org/10.1155/2015/860381.

Wang ZY, He WJ, Zhou WB, Zeng GZ, Yin ZQ , Zhao SX, Tan NH. 2014. Two new phenylpropanoids from Micromelum integerrimum. Chin J Nat Med 2 (8): 619-622.

WHO. 2001. General Guidelines for Methodologies on Research and Evaluation of Traditional Medicine. WHO, Geneva, Switzerland.

Xie H, Huang S, Deng H, Wu Z, Ji A. 1998. Study on chemical components of Momordica charantia. Zhong Yao Cai 21: 458-459.

Yong JWH, Ge L, Fei YN, Tan SN. 2009. The chemical composition and biological properties of coconut (Cocos nucifera $\mathrm{L}$.) water. Molecules 14: 5144-5164. doi:10.3390/molecules14125144.

Yoshida M, Fuchigami M, Nagao T, Okabe H, Matsunaga K, Takata J, Karube Y, Tsuchihashi R, Kinjo J, Mihashi K, Fujioka T. 2005. Antiproliferative constituents from umbelliferae plants VII. Active triterpenes and rosmarinic acid from Centella asiatica. Biol Pharm Bull 28: 173-175.

Yuan YR, He YN, Xiong JP, Xia ZX. 1999. Three-dimensional structure of beta-momorcharin at $2.55 \mathrm{~A}$ resolution. Acta Crystallogr 55: 11441151.

Zhao Z, Jin J, Lin C, Zhu C, Liu Y, Lin A et al. 2011. Two new chalcone glycosides from the stems of Entada phaseoloides. Fitoterapia 82 (7): 1102-1105.

Zulfiker AHM, Rahman MM, Hossain MKamal, Hamid K, Mazumder MEH, Rana MS. 2010. In vivo analgesic activity of ethanolic extracts of two medicinal plants-Scoparia dulcis L. and Ficus racemosa Linn. Biol Med 2 (2): 42-48. 